\title{
Clerics and Courtly Love in Andreas Capellanus' The Art of Courtly Love and Chaucer's Canterbury Tales
}

Andrew Williams

Université de Montréal

\begin{abstract}
In both The Canterbury Tales and The Art of Courtly Love Geoffrey Chaucer and Andreas Capellanus deal with various aspects of courtly love. In particular, both of them focus to some degree on the question of clerical celibacy. The use of tale telling and imaginary dialogues result in a contemporary overview of the role of the cleric in courtly love, the church rules on the subject, and the opinions of the people on a subject that is ripe for exploration. My aim is to point out some of the similarities that result when the question of «responsible celibacy» is considered.
\end{abstract}

In memory of Leslie Conrad

Much of Chaucer's Canterbury Tales is concerned with various aspects of love, courtly or otherwise. Of particular interest is Chaucer's treatment of clerics and courtly love. What is their position in the army of love? A work that deals with this topic, and may well have been at Chaucer's disposal was Andreas Capellanus' The Art of Courtly Love.

What is known of Andreas tells us that he was the court chaplin to Queen Eleanor of Aquitaine. Using the form of an address to a young acolyte, Andreas defines love and gives instructions on gaining, keeping, and getting rid of love. As a contemporary of writers such as Chrétien de. Troyes, Andreas was aware of the popularity of courtly writing -Dante's «sweet new style.» In his book Capellanus codifies the rules of the courtly love genre. These rules are central to the Canterbury Tales, many of whose tales are composed in the courtly and mock courtly genre. The Art of Courtly Love was translated from the Latin into French in the latter half of the twelfth century, and into German and Italian in the fourteenth and fifteenth centuries. It is unreasonable to believe that such a well read, travelled, and educated man as Chaucer would have been ignorant of such a popular work. ${ }^{1}$

Andreas deals specifically with what roles the clergy may play in love, as does Chaucer. As E. C. Ronquist puts it, «Andreas was a chaplin, thus a cleric, thus by his 
time in history obliged to maintain respectable celibacy.» These words apply equally to the characters that Chaucer has created.

This specific dealing with matters of love gives rise to the question of how the clergy learned about the practices of love. The crux of the matter hinges on the words «respectable celibacy.» What was it? If it allowed the cleric to enjoy the fruits of marriage, then he or she may have learned of the arts of love firsthand. If marriage was forbidden to the priests of the time, then clerical knowledge of the arts of love had to have been gained as the result of observation and book lore. Any other explanation results in a transgression against the laws of the church. This raises yet another question: what were the church opinions on the matter? The truth is that the church rules were subject to violent changes. Respectable is a word whose definition has varied throughout time. During the Middle Ages there were varied rules, customs, and practices regarding the sexual and or marital status of the clergy. The resulting conflicts can be found in the very core of courtly love, which is the result of «a certain inborn suffering. $\aleph^{2}$ It is a struggle between Nature and that which raises humans above the level of the beasts. This struggle has its counterpart in the Church dissention on the marital status of its clergy.

The aim of this paper is to examine some of the attitudes and influences that are displayed towards clerical love by both the clerical and non-clerical pilgrims in Chaucer's Canterbury Tales. This will be accomplished with an eye towards the influence of Andreas Capellanus' The Art of Courtly Love. It is my contention that the views expressed by Chaucer follow a form of road map provided by Andreas. As the codifier of conventions, Andreas indicates the correct placement of the cleric in Chaucer's army of love. Of necessity this essay will be confined to the sections dealing with matters of clerical love. With few exceptions these will be the tales of the clerics and their interchanges with fellow pilgrims. In Capellanus I will concentrate for the most part on parts VI, VII, and VIII of book I (dialogue eight, «The Love of the Clergy,» and "The Love of Nuns.»).

Capellanus' writing concerning the clergy can be divided into the following three sections: (1) Capellanus' attitude towards his own celibacy; (2) the attitudes that Capellanus shows concerning the celibacy of the clergy; (3) the attitudes that the characters in the dialogues display. In a similar manner, Chaucer also divides the views expressed on clerical love into several view points: (1) the pilgrims' views towards their own celibacy; (2) the view of the pilgrims towards each others' celibacy; (3) the views towards the celibacy of the characters created by the pilgrims in their tales.

In examining the first aspect of the grouping above, the reader can see that Andreas expresses something about his own feelings when he steps out of the narrative to address his acolyte, a young man called Walter, directly. Such a situation occurs in the author's preface. Andreas tells Walter that he has «learned from experience» that it does no good to think about anything except how to become further entangled in the chains of love. This leads to the question of what Andreas' experience actually was. This is made plain to us in book I, part VIII. Andreas tells Walter to «absolutely» avoid the love of nuns. The act of loving a nun results in the death of both body and soul. $\mathrm{He}$ explains further:

For one time when we had a chance to speak to a certain nun we spoke so well on the topic that, not being ignorant of the art of soliciting nuns, we forced her to assent to our desire. 
Capellanus tells the reader that he was smitten with what he terms «mental blindness» and forgot «what was seemly»:

In the meantime we realized that madness was carrying us away ... with a great effort [we] roused ourselves up from the deadly sleep ... we were barely able to avoid her pestilential snares and escape without contamination of the flesh. ${ }^{3}$

Andreas also tells Walter to avoid going to lonely places with nuns, as they will have no hesitation in "granting you what you desire.» Andreas specifies that this desire is to "carry out all of loves precepts in the other's embrace.» This small scene is the Middle Ages in a microcosm. Reason versus 'the beast,' or Nature, as some would have it. In this case reason wins out and Andreas escapes with his flesh free of contamination. In short, Andreas tells us that he has gained much of his experience by seducing nuns. The fact that he allows himself to reach such a situation shows that he is open in his attitude. Further proof of this is his comment directly regarding clerics and courtly love, namely, clerics shouldn't be involved in this earthly love, but if they are, they must enter the game at the social level of their parents.

Such direct expression of one's own experiences does not occur in the Tales. Rather, it occurs through its omission. None of the clerics actually discuss their own states of celibacy. It is their reaction to the other, often derogatory tales, that draw attention to their own attitudes. For example, after the rather scandalous Shipman's Tale, the Prioress relates a tale of a martyred boy and the 'pure' love of God. We shall see more of this pure love later. The monk seeks to impress the pilgrims with his learning by telling stories about famous people from the past. The host baits the monk by likening him to the monk in the Shipman's tale:

But, by my trouthe, I knowe nat youre name.

Wher shal I calle yow my lord daun John, Or daun Thomas, or elles daun Albon? ${ }^{4}$

The monk responds by saying that he will come up with something decent. The nun's priest is in the same boat as the monk. The clerical speakers attempt to guide the conversation onto a higher plane, not only for the «education» of the listeners, but to steer away from the impression that they too are clerics of the earthy type. As several of the tales note, many of the clerics of the time led lives that left much to be desired in the way of celibacy. It is quite proper to believe that the clerics would wish to avoid tales that would reflect ill on their status.

In the second grouping the reader must rely on the descriptions that the narrator provides. From these we may gain a clue not only as to how the pilgrims see each other, but what the popular attitude towards clerical sex was.

At the end of the Nun's Priest's Tale the host comments that the Priest seems to be of a type that if he had been «a secular,/Thou woldest ben a trede-foul aright.» The priest does not have the look of the cleric:

see, whiche braunnes hath this gentil preest,

So gret a nekke, and swich a large breest!

He loketh as a sperhauk with his yen ${ }^{5}$ 
By extension we must consider therefore the character of the Prioress. In the General Prologue Chaucer tells us that she is well versed in courtly behaviour, speaks French, good or bad as it may be, and has excellent table manners:

Ful semely after hire mete she raughte.

And sikerly she was of great desport, And ful plesaunt, and amyable of port, And peyned hire to countrefete cheere. ${ }^{6}$

Chaucer goes to pains to tell us that she is both good looking and well dressed. She also wears a brooch that bears the inscription «Amor vincit omnia,» or love vanquishes all. In his notes on the Prioress, Robinson points out that Chaucer has managed a fine mingling of both romantic and religious love symbols. He also points out that there are certain lapses in conduct, such as her wimple, her brooch, and her pet dogs. ${ }^{7}$ When one remembers that she is travelling with such an attractive looking priest the reader cannot fail but to consider the possibility that the prioress does not consider celibacy a requirement for the religious life. Possible considerations of this sort are often voiced by the pilgrims, for example the acrimonious exchange between the Friar and the Summoner.

From these observations we may at least derive some hint at what the feeling of the people towards church celibacy was. Barbara Tuchman notes that the

regular clergy detested the pardoner for undoing the work of penance ... monks and itinerant friars ... were notorious seducers of woman. Peddling furs and girdles for wenches and wives, and small gentle dogs «to get love of them.»

The Wife of Bath observes that wandering friars will do women «but dishonour.» ${ }^{9}$ The unflattering description that Tuchman provides is fitting for several of the clergy amongst the pilgrims. As the host has observed, the Priest is a manly figure. The monk is also singled out for similar attention by the host. In the prologue to The Monk's Tale, the host comments:

God yeve me sorwe, but, and I were a pope,

Nat oonly thou, but every myghty man,

Though he were shorn ful hye upon his pan,

Should have a wyf; for all the world is lorn. ${ }^{10}$

In his comments on clerical celibacy, the host complains that religion has taken all the «corn» and that what is left is producing weak examples of humanity. This is entirely in keeping with the views of Andreas. In The Art of Courtly Love the reader is told that the cleric is "the most noble class by virtue of his scared calling.» ${ }^{11}$ This calling comes from God and is granted to him by Divine Will. However, a cleric should not indulge in the arts of love, but should keep his body unspotted by filth. If the cleric does decide to love he will lose the special nobility that God has given him. Andreas adds a rider. Since almost no one can live without carnal sin, if a cleric wishes to enter in to the ranks of love, he must do so at the social standing of his parents. He must also obey the rules that govern courtly love conduct.

In The Shipman's Tale the reader sees that a monk has followed exactly these rules. A merchant and his wife often welcome the visits of a self styled cousin, a monk 
by the name of Sir John. He is fair and bold, the reader cannot help but associate him with the host's description of the monk, the possibly named Sir John. The Shipman's monk is very familiar with the courtly conventions and is made welcome by all in the household. Like Andreas, he "speaks well on the topic.» One day the monk and his cousin's wife are conversing in the garden. The monk reveals that they are not cousins and that he has only called himself such in order to be near the wife, whom he loves. The two engage in a conversation, much as Andreas and the nun did. She complains of her husband's tightfistedness and the monk agrees to lend her some money in return for a favour. In short, the money is obtained through a loan from the husband, and the monk is able to sleep with his «cousin's» wife. In choosing to call the cuckolded husband cousin, the monk establishes himself at a level equal in social standing. Thus the social level at which clerical love can be conducted falls in line with Andreas' rules, as does the secrecy with which the affair is carried out. Another factor of course is that the monk picks a married woman. This is also one of the tenants of courtly love and was not an uncommon act at the time, especially in regard to the clergy, many of whom "came to our dame when the gode man is from home.» ${ }^{12}$ In this case, art imitates life.

Perhaps the most telling of the grouping is the third. In the Tales, we find that the stories told by the non-clerical folk are often ribald, a seemingly natural reaction to the corruption found within the church at the time, monks and nuns having always been the subject of scurrilous tales. ${ }^{13}$ With the Parson's tale, however, Chaucer introduces a note that strikes true. The Parson is a "proper» churchman. His tale is couched in the form of a sermon on the seven deadly sins. Of these it is lechery that concerns us most, as it applies directly to the issue of sex and is linked to the arguments that Andreas puts forth throughout The Art of Courtly Love, but especially in dialogue eight. In this dialogue eight the reader is presented with a couple, both of the higher nobility, discussing whether or not the woman should give her love to the man. During this dialogue the subject of mixed and pure love is brought up. According to the man pure love «binds together the hearts of two lovers with every feeling of delight.» Pure love allows for

... the contemplation of the mind and the affection of the heart; it goes as far as the kiss and the embrace and the modest contact with the nude lover, omitting the final solace, for that is not permitted to those who wish to love purely. ${ }^{14}$

It is this type of love, according to the man, that is best and should be practiced by all. No one was ever hurt by such love, no one ever regretted it. No one can have enough of it and all excellence of character comes from it.

Mixed love is something else. It gets its effect from the delights of the flesh and «culminates in the final act of Venus.» It is the opposite of what the man defines as pure love:

What sort of love this is you may clearly see from what I have aiready said, for this kind quickly fails, and lasts but a short time, and one often regrets having practiced it; by it one's neighbor is injured, the Heavenly King offended, and from it come very great dangers. ${ }^{15}$

The man does not mean to condemn it, though. He simply prefers pure love. He tells the woman that she should not fear deception, but should choose which form of love 
she wishes. At this point the woman points out that the man has no business picking out any kind of love as he is a priest. He is one of the same sort that the Host, the Shipman, the Summoner and the Wife of Bath describe. The Parson is not. He terms lechery a «stynkynge synne.» ${ }^{16}$ If a man covets a woman, says the Parson, then he has committed the sin of lechery. He comments: «Heere may ye seen that nat oonly the ded of this synne is forboden, but eek the desir to doon that synne. ${ }^{17}$ For the Parson, the desire is the same as the act. The devil has five «fingers» to catch people out with in regard to lechery. They are: (1) Looking at a man or a woman in a lecherous manner. This is in effect Andreas' definition of love, the "excessive meditation" upon the opposite sex. (2) Touching the opposite sex in a wicked manner, such as the «modest contact» called for by the cleric in Andreas' dialogue eight. (3) Foul words that inflame the heart to desire. Words such as Andreas admits he uses to seduce a nun. (4) Kissing, which the Parson terms the same as laying one's mouth on an oven or furnace. The woman in dialogue eight wonders if anyone could have enough selfcontrol to resist sex when indulging in «modest contact» with a nude lover. She says: «Everyone would think it miraculous if a man could be placed in fire and not be burned.» ${ }^{18}$ (5) The final finger takes the form of lechery itself. Both Andreas and the Parson hold that lechers sin against that which raises us above the beasts. ${ }^{19}$

The Parson states that pre-marital sex is wrong, and in the case of virgins, is akin to being the victim of robbery. Like Andreas' clergy, virgins are lessened in spiritual purity as a result of their loss of virginity. In fact the Parson sets out his views on clerical celibacy in the strongest of terms. The sin of lechery is compounded if one or both of the sinners are members of the clergy. Andreas' man in dialogue eight reveals himself as a cleric. The two parties discuss the implications of this at length. The woman points out that a cleric should:

keep his body unspotted for the Lord, since the Lord has granted him privileges of such great dignity and rank that he may consecrate His flesh and blood with his own hands and by his words he may absolve the offences of sinners. ${ }^{20}$

It is the duty of the cleric to lead by example. The cleric argues that priests are human also. The duty of the clergy is to "make known the way of truth, both in church and among the people, and by his admonitions to confirm them in the true catholic faith. ${ }^{21}$ If he does this, then his burden is discharged and he is judged no harsher for his sins than the layman is. ${ }^{22}$ The Parson claims that the breaking of the vow of chastity aggravates the sin because:

thise ordered folk been specially titled to God, and of the special meignee of God, for which, whan they doon deedly synne, they been the special traytours of God and of his peple, to preye for the peple, and while they ben suche traitours, here preyer avayleth nat to the peple. ${ }^{23}$

This is in direct contradiction to what the cleric in Andreas' dialogue eight tells the woman. He claims that by preaching the true gospel, he will earn some form of bonus points with God. These points allow him to commit sin and still gain salvation. These two contradictory points can be traced back to a single origin.

The ancient Greeks credited man with logos, while admitting that he existed in the world of the animal. ${ }^{24}$ Made in the image of God, yet being animals, man rested on a 
plane that was somewhere under the supernatural and yet a notch above the finite. If a man is made in the image of God, the medieval philosophers reasoned, then the only way that they should consider going is up, towards God. Thus church thinkers such as St. Anselm arrive at phrases like fides quaerens intellectum, or as Julián Marias puts it:

Truth is not in the things, but in God; and man finds himself in God ... We reach God only through love, and only God is truth. ${ }^{25}$

If God is attainable only through love, then what is the problem with the possible practical knowledge that Andreas or any of the clergy in the Tales may or may not have attained? The problem is not so much with love as it is with sex. The church fathers didn't really like the idea of sex, and by extension, passionate love, possibly because they believed that involved a loss of logos and brought man down to the level of the beast, just as in their eyes it was responsible for the fall. It was a step back from God. C. S. Lewis attempts to pinpoint the reason for this dislike:

Gregory, at the end of the sixth century was perfectly clear on this question: for him the act is innocent but the desire is morally evil ... the concrete sexual act, that is the act plus its avoidable efficient cause, remains guilty. ${ }^{26}$

As time went by this view was modified:

Hugo of St. Victor agrees with Gregory in thinking the carnal desire «an evil.» But he does not think that this makes the concrete act guilty, provided it is 'excused' by the good ends of marriage, such as offspring. ${ }^{27}$

It is the later view that Chaucer's Parson adopts in his tale. The «trewe effect of mariage clenseth fornicacioun and replenysseth hooly chirche of good lynage.» Sex as sport is a «deedly synne. ${ }^{28}$

Other views abounded. Peter Lombard considered that evil was in «the desire and said that it was not a moral evil, but a punishment for the fall.» Lombard and Hugo provide us with two concepts close to the heart of Andreas. Hugo tells us that «a marriage caused by beauty is not marriage,» and Lombard that "passionate love of one's wife is adultery.» ${ }^{29}$

In any case, something involving the act was evil. But the church was hardly in a position to preach to anyone. Many of the clergy kept concubines or, in the case of the Shipman's priest, went calling. Things were bad enough that Odericus Vitalis, writing in 1119, tells us that Geoffrey, Archbishop of Rouen, threatened excommunication for anyone engaging in «commerce» with females. Vitalis goes onto say that the "priests shrunk from submitting to this grievous burden.» The resulting fistfight and subsequent riot prompted Geoffrey to take cover. Odo of Rigaud, writing in the thirteenth century, names more than fifteen priests (and often their companions) who had succumbed to the fleshy ways. ${ }^{30}$ At the end of the seventh century the Council of Trullo attempted to settle things by declaring «that Bishops must be celibate [but lower and younger] ... clergy, if already married when they were ordained, could continue normal married lives.» In 1123 and 1139 it was decided that marriage and priesthood did not mix and therefore previous decisions were revoked. ${ }^{31}$

By the eleventh century the time was ripe for reform and into the breach stepped the heretics. There was great fear and uncertainty regarding the religious implications 
of the turning of the millennium. Many felt that it would herald the return of Christ. This feeling of impending retribution remained in the minds of many over the years. As a result of this fear a wave of repentance swept much of Europe, including France. The momentum of this wave reached well into the twelfth century and beyond. These repentants preported to scorn earthly materialism and vice. Finding the institution to which they belonged to be riddled with immorality and corruption, they broke with the church. They

... would not accept piety as an institution, nor would they agree that priests were necessary as mediators between man and God. They regarded the clergy as superfluous, and wanted to destroy the church. ${ }^{32}$

Not surprisingly, the Church did something about this. The heretics were suppressed and scattered. One of the areas where this suppression was carried out was Champagne, Andreas' area of operations.

The two opposing sides did find a common ground however. Both of them condemned sex, the heretics in a much stronger manner than the moderates. The heretics' main argument against sex was found in Luke 20.34-36:

But those who have been counted worthy of gaining that system of things and the resurrection of the dead neither marry nor are given in marriage. In fact, neither can they die any more, for they are like the angels, and they are God's children by being children of the resurrection. ${ }^{33}$

They considered that this negated man's logos and stopped him rising to God. Chaucer's Parson does not condemn marriage. As we have seen earlier, he finds that it is a handy way of filling the pews. However, he cites one of the remedies against lechery as being chastity in marriage. This opinion echoes that expressed by the church in the early Middle Ages. The synod of Orleans pronounced that «bishop must treat his wife as his sister.." ${ }^{34}$ In order to ensure that chastity was maintained, chaperons were assigned to each married priest. Such an arrangement was far from effective. As Andreas comments, clerics were human and could sin too.

God is love, therefore were the heretics in denying love also denying God? The answer is that they did not deny love, just sex. Their refusal to acknowledge the sanctity of marriage (on the grounds that it was carnal) was met with approval by the less than pure of the clergy, feeling as they did that if no line was drawn between lawful marriage and concubinage there was little to worry about.

Georges Duby divides the antimarriage group into two parts. The first was that of the elite, amongst which are to be found those martyred for their heresies. The second was the «unlettered lay.» It is a mistake, says Duby, to confuse the two groups and think that their attitudes towards marriage were identical. They were not. They were divided into another two groups. The first was made up of "parfaits," or "perfect ones.» This group «insisted on continence if not virginity for everyone, so that all could become like angels.. ${ }^{35}$ This is more than reminiscent of Chaucer's Parson, when he tells us that the clergy «been» Angels and that a lecherous priest may be «likned to the aungel of derknesse transformed in the aungel of light ... but for sothe he is aungel of derknesse. ${ }^{36}$ This corresponds with Andreas' definition of the clergy as being the most 
noble of all men. The second group was not quite so noble. They just wanted to resist the Church's growing interference in their own marital affairs. ${ }^{37}$

It is clear that the reader must place Andreas within the «decent» body of the Church, as a result of the opinions that he has expressed in book I, parts VII and VIII. The cleric in dialogue eight, however, is a different matter. His real interest is to engage in sex with the woman. His arguments are that he proposes a "pure love,» that while clerics should not be placed apart from the bulk of males in regard to sex, they still have a special virtue or logos. Therefore, we must place the cleric in amongst Duby's second group of heretics, those who wanted to resist the church's interference in the clergy's sexual affairs. Chaucer's Parson is one of the old guard, upholding strict church rules and policies, celibacy in marriage is best, but sex is allowed if only to provide the church with faithful.

In conclusion it can be said that there are many parallels between Andreas and Chaucer's works. Both writers deal with matters of heavy religious natures, and both approach them in a similar manner. Both reflect the wavering of Church laws, as well as the attitudes of the thinkers and lay people of the time. It can be said that the notion of «respectable celibacy» provided the backbone of both writer's works.

What Chaucer and Andreas give the reader is a chronicle of the religious turmoil that surrounded the question of clerical celibacy, both from those involved and those without. Neither of them settle the question, but they do draw some lines for the reader to follow, and thus create a lens through which Medieval literature can be closely examined.

\section{Notes}

1. Sidney Painter, French Chivalry: Ideas and Practices in Medieval France (Ithaca, New York: Cornell UP, 1962), p. 122.

2. Andreas Capellanus, The Art of Courtly Love, trans. John Jay Parry (New York: W. W. Norton and Company, 1969).

3. Andreas, p. 143.

4. Geoffrey Chaucer, The Works of Geoffrey Chaucer, F. N. Robinson, ed., 2nd ed. (Boston: Houghton, 1957), p. 206, vv. 1928-30.

5. Chaucer, p. 206, vv. 3455-57.

6. Chaucer, p. 18, wv. 136-139.

7. Chaucer, p. 653.

8. Barbara Tuchman, $A$ Distant Mirror (New York: Ballantine Books, 1978), p. 30.

9. Chaucer, p. 84 , v. 881.

10. Chaucer, p. 189 , w. 1950-53.

11. Andreas, p. 142.

12. Tuchman, p. 30.

13. For more on this subject, see C. S. Lewis, The Allegory of Love (Oxford: Oxford UP, 1972), pp. 18-19.

14. Andreas, p. 122. An alternative translation is supplied in Painter, p. 118. "This moreover [pure love] consists in mental contemplation and affection of hearts; it proceeds to a kiss on the mouth, to many embraces, and to touching the nude private parts of the loved one. But never to the extreme solace. ... \&"

15. Andreas, p. 122.

16. Ibidem. 
17. Chaucer, p. 255 , vv. $845-846$.

18. Andreas, p. 123.

19. Andreas relates the lecher to a dog (Andreas, p. 33), and the Parson comments that lechery is a sin against reason, which tells man that it is a sin against God.

20. Andreas, p. 123.

21. Andreas, pp. 124-25.

22. Ibidem.

23. Chaucer, p. 257, w. 885-91.

24. According to the $O E D, \operatorname{logos}$ is arrived at through a metaphysical application of the terms 'reason' and 'word.' In Christian literature it is often taken to mean the second aspect of the Trinity.

25. Julián Marias, History of Philosophy (New York: Dover Publication, 1967), p. 136.

26. Lewis, p. 14.

27. Lewis, p. 14.

28. Chaucer, p. 259 , v. 936.

29. Lewis, p. 15.

30. James Bruce Ross and Mary Martin McLaughlin, The Portable Medieval Reader (New York: Penguin Books, 1982), pp. 78-82.

31. Frances and Joseph Gies, Marriage and the Family in the Middle Ages (New York: Harper and Row, 1989), pp. 59 y 135.

32. Georges Duby, The Knight the Lady and the Priest: The Making of Modern Marriage in Medieval France, trans. Barbara Bray (Toronto: Random House, 1983).

33. New World Translation of the Holy Scriptures, 7th printing (New York: Watch Tower Bible and Tract Society of Pennsylvania, n. d.), p. 1114.

34. Gies, p. 58.

35. Duby, p. 110.

36. Chaucer, p. 257 , v. 896-99.

37. Duby, p. 110.

\section{Bibliography}

Capellanus, Andreas. The Art of Courtly Love. Trans. John Jay Parry. New York: W. W. Norton, 1969.

Chaucer, Geoffrey. The Works of Geoffrey Chaucer. Ed. F. N. Robinson. Boston: Houghton Mifflin, 1957.

Duby, Georges. The Knight, the Lady, and the Priest: The Making of Modern Marriage in Medieval France. Trans. Barbara Bray. Toronto: Random House, 1983

Gies, Frances, and Joseph Gies. Marriage and the Family in the Middle Ages. New York: Harper and Row, 1989.

Lewis, C. S. The Allegory of Love. Oxford: Oxford UP, 1972.

Marías, Julián. History of Philosophy. New York: Dover Publications, 1967.

New World Translation of the Holy Scriptures. 7th printing, New York: Watch Tower Bible and Tract Society of Pennsylvania, n. d.

Painter, Sidney. French Chivalry: Ideas and Practices in Medieval France. Ithaca, New York: Great Seal Books, Cornell UP, 1962.

Ross, James Bruce, and Mary Martin McLaughlin. The Portable Medieval Reader. New York: Penguin Books, 1982.

Tuchman, Barbara. A Distant Mirror: The Calamitous Fourteenth Century. New York: Ballantine Books, 1978. 